\title{
Gift and Market in the Chinese Religious Economy
}

\author{
Published in Religion 41:4 (2011) pp. 1-26
}

\author{
David A. Palmer \\ The University of Hong Kong \\ Dept. of Sociology
}

\begin{abstract}
Religious market theory has figured prominently in recent scholarly debates in the social scientific study of religion in China. This article argues that the existence of "religious markets" should not be assumed as axiomatic but should be investigated as concrete social processes, distinguishing between market and non-market relations. Based on field research among popular religious and spiritual groups in China and drawing on the literature of economic anthropology, I propose an alternative model of a "religious gift economy" constituted by gifting exchanges between humans and between gods and humans. Five ethnographic cases from China illustrate the operation and coexistence of gift and market exchanges. In contemporary China, there is a tendency towards an increasing marketization of religion, with a simultaneous growth of religious movements explicitly offering nonmarket forms of sociality. Rather than subsuming all exchanges under the blanket concept of the market, studies of religion must be attentive to the distinct logics of different models of exchange.
\end{abstract}

\section{Keywords:}

Religious economy, gift economy, religious market, China, economic anthropology

Religious market theory treats religious organizations as firms competing for market share among potential adherents within a religious economy consisting of all the religious activity in a society. This model has in the past decade become one of the main theoretical currents in the sociology of religion in the United States (Stark and Bainbridge 1985; Stark and Bainbridge 1996 [1987]; Iannacone 1991; Stark and Finke 2000). It has also been the subject of discussion among scholars of religion in China including sociologists, anthropologists, historians and sinologists, and has been applied by scholars to analyse sets of religious groups and practitioners ranging from the $14^{\text {th }}$ century to the present, in Taiwan, mainland China and Hong Kong, and covering salvationist movements and redemptive 
societies (Seiwert 2003; Lu 2008), communal temples (Lang, Chan and Ragvald 2005; Chan and Lang 2011), self-cultivation masters (Goossaert 2011), and Falun Gong (Lu 2005). It has also been used and modified to explain the overall dynamics of religious change in China under a socialist regime (F. Yang 2006; 2010), and has stimulated heated debates among scholars and policymakers in the Peoples' Republic of China.

These theoretical models, studies and debates have provided a fruitful stimulus to the development of social scientific approaches to the study of Chinese religion, and to the testing and modification of theories developed in a primarily Protestant, American context to a culture, history and political system so vastly different as China's. While the religious market model has been criticised for being overly derived from Western Christianity and thus inapplicable to other areas and religious cultures (Sharot 2002), the published evidence so far demonstrates that the model, often in modified form, can be applied in Chinese cases, providing insights into the dynamics of the Chinese religious sphere. However, I argue that these insights may come at the cost of misreading the basic social processes at the heart of religious life.

\section{Literal or metaphorical markets?}

It is tempting to use the language of the market to describe the competition among religious groups. One aspect is competition for members. The pool of potential members can be treated as a market, in which there is a demand for religion, and religious groups act as firms, competing with each other to satisfy that demand. While economic theorists postulate that all human activity is economic, they also tend to follow the false assumption that all economic activity is analogous to the exchanges between commercial enterprises and their customers. In "Definition 32" of Starke and Finke's theory, for example, "A religious economy consists of all the religious activity going on in any society: a "market" of current and potential adherents, a set of one or more organizations seeking to attract and maintain adherents, and the religious culture offered by the organization(s)." (Stark and Finke 2000: 283). Elsewhere, religious organizations are described as firms competing with each other to offer rewards to current and potential adherents; free competition in an unregulated religious 
market leads to them becoming more dynamic and effective (Stark and Finke 2000: 194-195, 218-220). These definitions transplant onto the religious field a logic of commercial firms competing for market share, positioning themselves strategically to maximise and expand the number of adepts.

The dictionary definition of a market is derived from the archaic meaning of "the act or an instance of buying and selling"; and designates "a meeting together of people for the purpose of trade by private purchase and sale and usually not by auction" or "the area of economic activity in which buyers and sellers come together and the forces of supply and demand affect prices" (Merriam-Webster.com, italics added). What all these references to buyers and sellers, buying and selling, private purchase and sale, prices and so on refer to is the exchange of commodities for money or its equivalent. When such an exchange occurs, as a private purchase between a buyer and seller, there is a market. To the extent that a religious organization is engaged in producing and selling commodities, it can be counted as a commercial firm. However, as I demonstrate below, there are fundamental differences and even dynamic tensions between commercial markets in the strict sense of the term, and the religious markets described by sociologists. This begs the question of whether it is appropriate to use market metaphors to theorize social relations in which the abovementioned conditions do not apply, and which are not characterized by buying and selling.

The religious market model is based on the blanket use of a market metaphor to explain all social relations and all religious phenomena. The chief proponents of the market model - Stark, Bainbridge, Finke and Iannacone - insist that they do not use markets as a metaphor, but as a reality - religion is a market (Stark and Finke 2000: 36), consisting of buyers and sellers, consumers and producers (Iannacone 1995: 77). Perhaps the issue is purely one of semantics, religious market theorists preferring to include within a single, more encompassing concept of the market, what belongs to quite distinct classes of social relations. If it were simply a question of choice of words, there would be little need to spill much ink on this debate. But behind a seemingly innocuous choice of words lies what the religious market theorists themselves proclaim to be a "paradigm shift." While the new paradigm aims to challenge the dominance of the worn-out secularization thesis in the sociology of religion, it also implies a shift in emphasis in the types of questions and answers to be posed by social scientists. 
Indeed, in the economic paradigm, forms of social relations are relevant primarily to the extent that they affect changes in market share. In his study of the rise of Christianity, Stark claims that among the many factors which led Christianity to become the Roman Empire's dominant religion was that Christianity was a radically new type of community, leading to higher levels of mutual care and cohesion, a higher status of women, a higher level of inter-ethnic solidarity, and other aspects, in relation to the pagan forms of religious organization of the time. The nature of such a community would appear to be of fundamental sociological importance - but, for Stark, these aspects are of interest only to the extent that they are causal factors in the increase in numbers of Christian converts. Indeed, the question that really matters in the market theory of religion is identifying the "winners and losers" according to market share (Finke and Stark 1992).

In his study of Christianity's competition against paganism in the Roman empire, Stark stresses how most pagan cults were client cults in which gods and priests were approached in a logic of commercial transactions, limiting the sense of community and belonging of pagan cults, compared to early Christian groups, which became known for practicing the love of one's neighbour more intensely than other groups, creating stronger bonds. "You did not approach Christian clergy to purchase religious goods, but to be guided in fulfilling the religious life. Nor were the clergy distanced from their flocks - they were not an initiated elite holding back arcane secrets, but teachers and friends, selected, as [the famous Christian apologist] Tertullian explained, 'not by purchase, but by established character'." Stark goes on to quote a telling passage from the apologist:

"There is no buying and selling of any sort in the things of God. Though we have our treasure-chest, it is not made up of purchase-money, as of a religion that has its price. On the monthly day, if he likes, each puts in a small donation; but only if it be his pleasure, and only if he is able; for there is no compulsion; all is voluntary. These gifts are, as it were, piety's deposit fund."(Stark 1996).

It is ironic that, according to Stark, the "winner" in the Roman religious market was the religion which was the least marketized, and it was precisely those non-commercial features which made it so attractive. If early Christianity owes its success to being so unlike a commercial firm, one is led to wonder if the behaviour of firms in a market can be an accurate model for the dynamics of religious movements? 
The same question comes to mind if we consider Stark and Bainbridge's earlier work on new religious movements. In The Future of Religion, they make a strong distinction between "audience cults" and "client cults" on the one hand -- which, according to Stark and Bainbridge, are not fully-fledged religions -- and what they call the fully religious cult and sect movements on the other hand, which can mobilise the long-term, sustained commitment of their followers. The distinction they offer is that audience and client cults cannot generate sustained commitment because they only offer magic, in the form of weak, specific "compensators" often lacking supernatural content and which can be disproved by science, while religions offer general compensators or explanations which are less vulnerable to scientific disproof and require long-term commitment to be obtained (Stark and Bainbridge 1985: 32-33). Stark and Bainbridge base their categorization on the content of beliefs, relying on contested distinctions between magic, the supernatural, science and religion, and compensators. Strangely, as market theorists, they omit to note the objective sociological distinction between the two: audience and client cults operate as commercial firms selling books, films, lectures and services to clients, whereas cult or sect movements are not in the business of one-off or periodic commercial transactions. The long-term loyalty and commitment of adherents may well be directly related to the non-market structure of religious movements. And according to the religious market theory, in the competition between religious groups, the most successful ones are the higher-tension groups, those which generate a higher intensity of communal ties. These communal ties are qualitatively different from market relations, and, indeed, often constitute themselves consciously and explicitly in opposition to commercial transactions. Again, if the most successful groups are those which behave the least like commercial firms, we might question whether firms are the best model to describe them - and we might ask what does produce higher-intensity ties and commitment.

Stark and Finke are correct in placing relationships with gods at the centre of religious life. They note that the scriptures of many religions use a language of exchange, and promise quite explicit rewards for devotion to a god (Stark and Finke 2000: 40). Where they err is in modeling all forms of exchange on commercial transactions, using language such as how much "divine beings can charge for their favor", discussing the "price" of exchange, “periodic payments," and so on (p. 96, 99). Undoubtedly, as rational actors, people will tend to follow the most beneficial line of action (p. 36-39) - but it does not follow that the most 
beneficial line of action is always to behave like a consumer. Market exchanges are only one of many forms of exchange; not all costs, rewards and relationships can be subsumed into a market.

Both of Stark's examples of Roman paganism vs. early Christianity, and of contemporary North American "audience" and "client" cults vs. religious "movements," reveal an opposition between different forms of social exchange: (1) markets for magic/religious commodities according to the strict definition of the term, in which products and services are bought and sold, and which are contrasted with (2) exchanges which create religious communities and movements on a non-market basis. Notwithstanding the theorists' denials, we can only treat as metaphorical the use of market concepts to analyse the latter type of exchange. To be sure, it can be useful to use various metaphors to gain insight on social reality, just as we may speak of the "marketplace of ideas" or so on. But if the "metaphorical" firms are organized along fundamentally different principles than "literal" firms, and if it is this difference which defines them as more purely "religious" and explains their sustained growth and membership commitment, then we might be well advised to closely examine the difference between the two, and question the utility of the metaphor.

The market model works best as a metaphor in the case of the dynamics of competition between expansionist salvationist movements - which, in the Chinese context, can include redemptive societies such as Yiguandao 一貫道, Falungong 法輪功, and many Chinese Christian sects (see Palmer 2011b). Since these groups are not commercial firms and do not literally "sell" salvation, they do not constitute a market in the strict sense of the term. However, to the degree that salvationist groups consider themselves to be the sole path to salvation, discourage or forbid participation in other religious or spiritual movements than their own, consider salvation to be a primarily individual matter, consider salvation to be achieved at the moment of initiation or joining, are committed to unlimited expansion, and subscribe to apocalyptic prophecies which give a sense of intense urgency to their mission, such groups enter a logic in which numerical growth may tend to become their ultimate purpose as an organization. And to the degree that they exclude membership or participation in other religions, these groups' growth becomes a zero-sum game in which one group's growth will often be achieved at the expense of others. Although such groups 
are not commercial firms, the dynamic engendered by this model of exclusivist individual salvationism is, in many ways, similar to the logic of a marketplace, in which religious sects compete with each other to recruit adherents and increase "market share". We thus end up with the dynamic described by Stark and Finke of 'a "market" of current and potential adherents, a set of one or more organizations seeking to attract and maintain adherents, and the religious culture offered by the organization(s).' Indeed, the religious market model is derived precisely from the dynamics of competition between exclusivist salvationist sects, which are the most dynamic component of the American religious culture. But on the other hand, these groups' emphasis on moral purity and detachment from worldly desires, and their duty to share the path to salvation for free, as a gift to others - generates social relations among followers, and between followers and non-followers, which cannot be created through market transactions. Thus, we can speak here of a metaphorical or quasi-market, and not of a market in the strict sense of the term. This quasi-market is of a quite different nature than commercial markets for religious books, objects, rituals, healings and other services. And, as will be shown through the examples below, it constitutes only a part of the overall field of non-market religious activity.

\section{An alternative model: the religious gift economy}

The uncritical extension of market metaphors and models to non-market relations and exchanges, making no theoretical difference between commercial transactions and other forms of exchange, may produce a dangerous conceptual blind spot and obscure a fundamental theme in the religious formation of social relations. I contend that there is a significant difference between market transactions in the strict sense of the term, and other forms of human relations and exhanges.

Taking an anthropological standpoint, I argue that, rather than beginning with the $a$ priori assumption that all human activity consists of market exchanges, human interactions should be observed and described empirically, and models inductively constructed from recurring patterns of observable human relations. Applied to the economic realm, concrete forms of production, distribution, circulation and exchange should be described and categorized in terms of their distinct patterns and structures. The economist Karl Polanyi 
articulated this position most forcefully when he criticized the "economistic fallacy" which consists of "equating the human economy in general with its market form [...] to stretch the concept of the market until it embraces all economic phenomena is artificially to invest all things economic with the peculiar characteristics that accompany the phenomenon of the market." (Polanyi 1977: 5-6) Shifting the focus from supply and demand, Polanyi defined the human economy as "an institutionalized process of interaction which functions to provide material means in a society" (1977: 34), and drew the attention of economists to non-market economic institutions, such as reciprocity and redistribution (Polanyi 1968). Anthropologist Marshall Sahlins offered a similar definition of the economy, as "the process of (materially) provisioning society" (Sahlins 2004 [1974]: 185 n.1, 187 n.2), building on a long tradition of research in economic anthropology stimulated by classic works by Malinowski on the kula ring of the Trobiand Islanders (1922) and by Marcel Mauss on the gift (1967 [1925]).

I will not dwell here on the problem of using a market model to understand the social provision of spiritual means by religion, stretching the economistic fallacy even further than that critiqued by Polanyi, applying market paradigms outside the economy itself. Rather, my focus here is on the economic dimension of religion. As social organizations, religious groups receive, manage and use material and human resources. They have their own internal economies, and, as important nodes of social relations, they play important roles in the general economy. A growing body of work on Buddhist monasticism in Chinese history, for example, has documented its role in the general economic organization of mediaeval and late imperial Chinese society (Gernet 1998; Kieschnick 2003). Other studies have analysed the interplay between ritual systems, the flow of capital, and political authority in Chinese history (Duara 1988; Gates 1996) and in contemporary popular religion (M. Yang 2000: 480; Dean 2009). As the latter studies have illustrated, what Mayfair Yang and Kenneth Dean call the "ritual economy" in Southeast China - which accounts for a large proportion of economic activity in some areas -- produces quite different pathways of capital flows than in the market economy.

Economic anthropologists have proposed several typologies of forms of economic exchange. These generally posit a distinction between the "market economy" and the "gift economy," with many studies exploring the logic of the gift and its social implications. Marcel Mauss, in The Gift, defined the object of his inquiry as "prestations which are in 
theory voluntary, disinterested and spontaneous, but are in fact obligatory and interested" (Mauss 1967 [1925]: 1). He noted that in primitive societies, there was little exchange of goods between individuals through markets; rather, most exchanges took the form of gifts between groups - clans, tribes, and families - which exchanged not only goods and material wealth, but also "courtesies, entertainments, ritual, military assistance, women, children, dances, and feasts; and fairs in which the market is but one element and the circulation of wealth but one part of a wide and enduring contract. Finally, although the prestations and counter-prestations take place under a voluntary guise they are in essence strictly obligatory, and their sanction is private or open warfare" (3). Mauss viewed the gift as a "total social phenomenon" which gave expression to the religious, legal, moral, and economic institutions of society. He identified three distinct obligations in the process of gift exchange: the obligation to give, the obligation to receive, and the obligation to repay (37-41), producing the endless cycles of ritualized gift exchanges, "imbued with religious elements", "impregnated with ritual and myth" (70), which constitute the pattern of social relations in traditional societies. These exchanges do not conform to the principles of "utilitarian" economics, with exchanges "couched in terms of purchase and sale," based on "the calculation of individual needs" $(63,69,75)$. Finally, it is gift exchange and obligation which transform "war, isolation and stagnation" into the social bonds which are the foundation of civility (80-81, also Sahlins 2004 [1972]: 149-184).

Mauss's insights have stimulated a vast literature and many debates among anthropologists, which it is beyond the scope of this paper to summarize here (see Sykes 2005). It is important to remember that the concept of the gift and gift economy does not designate a single, monolithic rule, but subsumes an extremely wide range of forms of exchange and reciprocity, which some scholars have attempted to categorize according to a polarity ranging from the "solidary extreme" of "generalised reciprocity" between close kin to the mid-point of "balanced reciprocity" between more distant relations and ending at the "unsociable extreme" of "negative reciprocity" of raids and tit-for-tat (Sahlins 2004[1972]: 193-196). For the purpose of the present discussion, I retain the following points from this literature: 
1. A "gift" is defined not by the nature of the thing given (which can be material, hospitality, labour, or any form of help or assistance) but by the nature of the exchange, as outlined below.

2. A gift is inalienable, in that, once given, it retains a connection to the original giver. Gifts are remembered and their stories are part of the memories of the things exchanged and of the relationships between those who give and receive (Gregory 1982; Weiner 1992.)

3. A gift is a moral act which enacts norms of what it means to be a person of honour and moral worth, and brings into play principles and emotions of generosity and gratitude. It creates an imbalance between the moral superiority of the giver and the obligation and indebtedness of the receiver; an imbalance which can be redressed through reciprocation at a later time (M. Yang 1994).

4. Gifting enacts existing social relationships or establishes new ones. Social relationships of many kinds can be mapped by plotting sequences of gift exchanges. At high levels of social solidarity, gifting is continual and indeterminate, and there is little mental "accounting" of precise gifts and reciprocation (such as within the members of a household, or between very close kin), while, in more distant social relations, mental accounting does occur, and failure to reciprocate in the proper manner may jeopardize the relationship. Through paternalistic generosity (noblesse oblige) and grateful servitude, gifting can instantiate and legitimize social hierarchies. On the other hand, agonistic and competitive giving can also occur between parties jostling for moral superiority over each other (Sahlins 2004 [1972]).

5. Gifting combines altruism and self-interest, freedom and obligation in subtle and ambiguous ways. It would be entirely misleading to analyse gifting according to any single one of these terms.

6. There are other inalienable possessions which are off limits (or severely restricted) in gift exchange: sacred objects, memories or knowledge which constitute the core of a group's identity and existence. These possessions cannot be legitimately transferred to anyone else. The only way one can attain them is to become part of the group which 
possesses them, through alliance, initiation or conversion: a change of identity and ontological transformation of the person (Weiner 1992; Godelier 1996).

7. The "gift" can be contrasted to the "commodity" on all of the above points. The commodity is also defined by the nature of the exchange which constitutes it: the commercial transaction of alienable objects, in which payment is immediate and equivalent, theoretically involving no social relationship beyond the single transaction; past owners have no rights on new owners and the latter have no obligations to previous owners. Rather than establishing or maintaining social relations, the purpose of commodity exchange is meeting the demand for specific goods (Gregory 1982).

8. Gift and market economies co-exist in the same societies: one is not exclusive to traditional cultures and the other to modern cultures. A legitimate space for haggling, markets, and short-term acquisitive economic behaviour co-exists with the more morally-laden norms of gift exchange and long-term sacred obligations. The line between the two economies, however, may be ambiguous and shifting. When the former is seen as encroaching on the latter, however, it generates a discourse of moral outrage and rejection of the "evil" nature of markets and money (Bloch and Parry 1989).

To these points discussed at length in the literature, I would like to add another aspect which was only briefly alluded to by Mauss and, though developed by Godelier (1996), its significance to the entire gift economy has not been fully measured. This pertains to the gift exchanges between humans and gods, bringing us to the heart of our discussion of religion. A few aspects of these exchanges are worth mentioning here:

1. A cult to a god is usually established and maintained to repay the god for some blessing or favour and, through continued offerings of gifts, hoping that future blessings will be conferred. A religious cult is thus a gift exchange between gods and humans, with both parties engaged in cycles of giving, to receiving, and repaying each other. This type of relationship can exist between the god and collective bodies such as families, lineages, geographic communties or religious congregations, and between the god and individuals. 
2. Since gods do not physically remove the offerings they receive to another world, the offerings are in fact often redistributed to the community. If the gift is an animal offered in sacrifice, it is consumed in a communal feast; if the gift is offering one's life in service to the god, the concrete acts of service, charity and compassion are directed to others. The organization which manages a cult comes into being thanks to these gifts and is essentially their trustee. Its responsibility is to manage the collective exchanges with the god and to allocate and redistribute the resources generated by the cult. Gifts to gods, therefore, create community, organization and redistributive networks in a very tangible way. They constitute an important node in the overall gift economy.

3. The redistributive nature of gifts to gods reveals the existence of a distinct type of gifting relationship. In reciprocal gifting in the Maussian sense, the giver expects delayed reciprocity from the receiver. It is a dyadic relationship between the two parties only. In a religious gift economy, the god - or a spiritual reality or principle such as karma - is a third partner in the exchange. In this case, a gift is dedicated to a god, but actually given to another person. It is the god who will reward the giver, and not the actual recipient of the gift. Or, put in other terms, a gift may be given to another person, but the recipient is not expected to reciprocate: the giver knows that he will benefit from future divine or karmic recompense. The giver need not expect anything in return from the actual receiver of the gift. In fact, as noted by Philip Clart in his study of Taiwanese morality books, in the case of gifts anonymously given or received, there may no direct contact between the giver and receiver - but the receiver may reciprocate to the god and/or to others (Clart 2009: 141142). The "third partner" opens the way for charity and all other forms of religious altruism.

Now, out of a sense of gratitude or obligation, the recipient may want to repay the gift - but, instead of reciprocating to the original giver, he may repay the god, joining the community of those engaged in its worship. And that offering may be expressed through yet another act of generosity or compassion to others - thus further expanding the network of giving. These three-party chains of exchange between gods and humans constitute a religious gift economy, which is distinct from the reciprocal dyads in which gods or spiritual causality are absent. 
On the basis of the above points, we can thus say that the cult of a god is the nexus of a gift economy, founded on giving between the god and humans, and between humans. A religious community is formed by the mutual generation of these gifting relationships. And to the extent that such exchanges, and the obligations they generate, are extended outward or not, the community may grow or contract. I submit that this "religious gift economy" model of religious groups offers a more empirically accurate framework than the "religious firms" concept for understanding many (though certainly not all) forms of non-market religious relations.

\section{Ethnographic cases}

In the following section, I offer five ethnographic cases of contemporary Chinese spiritual/religious organizations taken from my ethnographic research, examining their

patterns of social relations and exchange, identifying those patterns that constitute gift and market relations, and analysing how the actors define and position themselves in relation to marketization: popular communal cults in rural Northern Guangdong and urban Hong Kong; qigong networks in Chengdu in the 1990's; Daoist cultivators; Confucian volunteers; and Buddhist philanthropists. Analysed in reference to the broader scholarship on these forms of Chinese religiosity, in each case we can identify the simultaneous operation of gift and market economies. In some cases, we can also identify a trend of "marketization" in which previously non-market forms of religiosity are brought into the logic of market relations. We can also see how this trend is opposed by discourses and practices critical of religious commodification, creating a counter-trend of "anti-marketization" of religious life.

\section{Chinese communal religion}

In the township of Huanghua 黃花 in Yingde 英德 County, some $250 \mathrm{~km}$ north of Guangzhou, as well as many surrounding townships, traditional religious culture is lively and, in the villages where I conducted fieldwork during several trips between 2004 and 2008, the 
important ritual cycles continued even during the Cultural Revolution (1966-1976). Each alliance of villages has its own temple at which several local deities are worshipped, including the creator god Pangu 盤古 and the local goddess Caozu 曹祖娘娘. The main activities of each temple are communal jiao 醮 rituals held in cycles of one, three and five years, with the largest rituals -- lasting four days and three nights -- occurring at five-year intervals. Jiao rituals are also conducted for the renovation and consecration of temples. Each temple's rituals are organized by a committee of senior male representatives of each village which is a member of the ritual alliance. Most villages are dominated by a single lineage. There are two dominant and several minor lineages in the ritual alliance, which consists of around two dozen villages within walking distance of the temple, sharing a plain connected by river to the market town of Huanghua. Besides the government-managed primary school and village government office (a small house containing the village committee desk, the Party committee meeting room, and a classroom for family planning lessons), the temple is the only other public building in the area and the only self-governed non-kinship-based local association. The temple committee hires a troupe of priests, called nan-mouh 喃嘸, to conduct the periodic jiao rituals. The priests combine two liturgies, one Buddhist and one of the Lüshan 閭山 Daoist tradition, which they perform simultaneously at two altars designated respectively as the "civil" wen 文 and "martial" wu 武 altars. Most priests are peasants who work part-time as ritual specialists. They all share the same repertoire which includes not only jiao liturgies but also funerals, birth rituals, and healing rites. They are trained in ritual techniques as disciples of a senior priest, but operate independently and serve individual clients and temples throughout the area which shares the same ritual traditions. When a temple decides to hold a jiao, it contracts the ritual to a senior priest, who will then hire and direct an ad hoc troupe of a dozen priests required to perform the necessary rites. In order to cover the costs of the ritual, which includes not only the priests' salaries but also the temporary altars, sheds, petitions to the gods and other paper paraphernalia which will be offered and burned, the temple committee collects an obligatory cash contribution from each household in the villages of the ritual alliance, as well as voluntary donations from villagers who wish to offer more than the obligatory fee. The names of all contributors are meticulously recorded on rolls which are, during the rites, communicated to the gods by chanting and burning. Voluntary donors also carry home a framed certificate which they 
proudly display in their homes. All contributions, whether obligatory or voluntary, are in effect made to the gods, to pay for the resplendent ritual offerings which are a gift to honour and glorify the gods. The temple committee is the trustee of these funds, and posts detailed accounts on the temple walls. During the jiao ritual, women bring offerings of tea, fruit, and dried tofu to the gods, representing their households and hoping that the gods will respond by conferring blessings on their families (Palmer 2011c; Tam 2009).

From this brief description, we can identify several of Chau's "modalities" of doing religion (see Chau, this issue) and several types of relationships and exchanges, some of which are clearly economic in nature. But is this a religious market? There is clearly a market for ritual services: funerals, healing rites, and jiao rituals, which are performed by priests who offer their services for hire in a manner analogous to a petty capitalist craftsman, freelance actor or family enterprise (Chau 2006b). However, this market for ritual services represents only a segment of the "religious economy." Firstly, the priests' liturgies are only part of the total activity of the "event production" of a ritual; much of the coordination, labour, materials, cooking, music, and other elements are provided for free by the non-specialist clients themselves and their networks of kin and neighbours, drawing on the common knowledge and abilities diffused in the general culture (Chau 2005a), and offered in the context of the gift economy. Secondly, the main religious institution, the temple, is communal property, built and financed collectively by the resident households of the alliance, and managed by the senior men of moral stature whom they designate as their representatives, and who carry out their roles in a volunteer capacity. The temple committee is not into the business of selling religious services; rather, through staging rituals, it maintains a gifting relationship with the gods, seeking to secure divine blessings and protection for the community that built the temple. Thus, the temple and its rituals, rather than a firm providing services to clients external to itself, are the material embodiment of the gifting relation with the gods, which itself secures the alliance between the member villages.

Though there are many temples in the area, each temple represents a distinct alliance of villages. Temples compete to stage more grandiose rituals, but this competition is a rivalry for prestige among neighbours, and not market competition to attract new customers (Eng and Lin 2002). Indeed, the membership base of a temple is fixed, since it is ascriptive - all residents of the alliance villages are automatically members, and non-residents cannot join. 
The ritual culture in this community is simpler than that described in other studies of rural Chinese popular religion, which may include overlapping ritual alliances, an intense ritual calendar, and a wide range of ritual specialists competing with or complementary to each other (see notably Dean 1993; 1998; Chau 2006b; Dean and Zheng 2010). In the "ritual polytropy" described by Chau in his contribution to this issue, some ritual specialists are hired in a commercial transaction, while others - the Confucians - do not collect a fee and are thanked with gifts, earning them the reputation of being "morally superior". In other cases, notably in parts of North China, liturgies are extremely simple and can be conducted without hiring priests, or are offered for free or for a fee by amateur scripture-recitation groups (Jones 2011). These cases show that the market for ritual services varies in size and structure in different regions, within a broader religious culture which involves forms of gift exchange ranging from self-production, reciprocal exchanges, and amateur volunteer service. And in most of these cases, village temples are self-governing community associations with ascriptive membership, rather than commercial firms serving voluntary clients.

In large cities and tourist areas, however, a different pattern can be observed. In Hong Kong, for instance, funerals have become entirely commercialized. Daoist priests are organized in firms which offer set menus of complete, standardized and convenient funeral packages for busy urban workers. The clients have no relationship with the priests before or after the transaction, and need not organize or provide anything themselves (Chan 2003). At the same time, there is growing competition in the market for jiao communal ritual services for the indigenous villages of the New Territories, as some urban Daoist temples have begun offering Quanzhen jiao liturgies for a lower cost than the Zhengyi priests who have traditionally served the villages (Lai, Yau and Wu 2009). In contrast to the rural Guangdong temple I described above, urban Hong Kong residents (with the exception of indigenous villagers of the New Territories) have no ascriptive ties to a community temple and ritual cycle of their own; they go to temples only as individuals to pray for blessings for themselves and their families, are entirely free to choose which temple to visit, if at all, and, for the most part, have no sustained relationship with the temple, or any relationship with temple staff or other worshippers. In such a context, temples become more like providers of services to individual clients. In addition to providing free access to a shrine for worshipping, they may also provide fee-charging services for fortune-telling, sell paper incense and paper offerings, rent lamps for blessings in the shrine halls, and -- especially lucrative -- rent niches for 
storing funerary urns. Temples are thus present in several markets and compete not only with other temples but also with non-temple-based fortune-tellers, columbariums, and freelance ritual specialists for the paid custom of worshippers within the same population, who can choose among several temples and other service providers. Factors such as location, convenience of transportation, adaptability and responsiveness to demand thus play a role in the relative popularity of different temples, such as Wong Tai Sin, the most popular temple in Hong Kong (Lang and Ragvald 1993). At the same time, most Hong Kong public urban temples are incorporated as charitable societies and managed by lay religious associations with their own sacred history and mission. At the core of these associations is their cult, a gifting relationship between the association and the deities or Buddhas, in which the building and expansion of the temple and its services can be construed as gift offerings to both the gods and to the community. They offer a range of free services such as Chinese medical clinics, activities for the elderly, government-subsidized primary schools and old age homes, and a range of philanthropic projects. Thus, Hong Kong temples operate simultaneously in the logics of the market, of philanthropy, and of publicly-funded social services. The excess revenue generated from the commercial or fee-collecting operations of temples serves to finance their philanthropic activities. The religious gift economy is at the core, while market activities are undertaken to funnel further resources into it.

In mainland China, another configuration often arises because the main urban and tourist temples are not owned and managed by autonomous communities - whether ascriptive as in traditional villages or neighbourhoods, or voluntary as in the associations that own the Hong Kong temples. They are either owned by state-sponsored Buddhist and Daoist associations and managed by monks and officials, or by other government departments such as Cultural Relics or Tourism. In the latter case, temples may be leased out to private entrepreneurs, who invest in the premises, hire monks as staff, and offer a range of products and services to generate income streams (Chan and Lang 2011). These temples operate under a fully commercial business model and see themselves competing for customers in a tourist and religious market. The religious gift economy is weak or absent in these operations.

The qigong boom of the 1990 s 
The Natural Gas Transportation Division of the Sichuan Petroleum Administration was a typical socialist “Work Unit” (danwei 單位) in the early 1990's, a self-contained compound of drab concrete blocks on a hill surrounded by rice paddies at some distance from the city of Chengdu, providing its 2000 employees with dormitories, a supermarket, a cinema, a fitness room, a karaoke hall, a school, a dispensary, a sports field, and a single street with an outdoor vegetable market and a few small restaurants and karaoke bars operated by local peasant entrepreneurs. The entire space was owned and controlled by the Work Unit, and there was no religious life of any sort. Most people had lived and worked in the Work Unit for decades, if not spent their whole life in it, and their only exposure to religious culture was through classical literature, images of Daoism and Buddhism gleaned from popular martial arts films and novels from Hong Kong, and notions of Christianity derived from British Victorian novels, recent Hollywood films, and Marxist theory. The workday was short and far from exhausting; there was much time for leisure, but, given the small size and relatively remote location of the Work Unit, few options were available. One popular activity was the practice of qigong breathing and gymnastic exercises in groups, usually early in the morning but also in the evening. Starting at dawn and until worktime, at various spots in the compound - the open space in front of the entrance to an office building; a basketball field; the fountain in front of the cinema - groups of qigong practitioners congregated and practiced the exercises in unison, led by a volunteer enthusiast, often to the rhythm of classical Chinese music playing on a tape recorder. Each group practiced a different method: one group of old ladies did “Fragrant Qigong” (xianggong 香功), another group, engineers on training from oilfields around China, did the "Numinous Qigong of the Nine Resonances” (jiuying shengong 九應神功), yet another group of residents, led by a primary school teacher, did "The Chinese Qigong for Nourishing Health and Increasing Intelligence” (zhonghua yangsheng yizhi gong 中華養生益智功) (Palmer 2008). In the urban parks of Chengdu, even more groups practicing different methods could be found, as well as people practicing ballroom dancing, disco dancing, fencing, playing chess, doing taijiquan, or reading English books aloud. The qigong groups were part of a larger culture of spontaneously organized early morning activities in parks and public spaces, a favourite occupation of seniors, but also common among middle-aged people and students. All these activities were free, and anyone could join in and learn by imitation. There was no formal 
membership in any group, and anyone could start a group in some free space or empty corner of the park (Farquhar 2009). Most qigong practitioners were primarily interested in the health benefits of the methods, and others went for the social support of the group activity, but the group leaders were often enthusiastic converts and promoters of the miraculous benefits of their method. They were usually graduates of intensive qigong workshops, usually lasting a few days to a few weeks, which were offered by a qigong master.

Each master had his own method, which he had either invented or claimed to have received in secret transmission before "coming out of the mountains" (chushan 出山) to publicly teach it to the masses. The method typically involved different types of exercises body movement, breathing techniques, meditation - which were organized into progressive levels. The masters were typically highly entrepreneurial, charismatic individuals who crafted an image of themselves as inheriting the powers of ancient wizards and immortals, and possessing miraculous healing powers. Their operations were made possible by a statesponsored organizational infrastructure, including qigong magazines which propelled masters into national fame through feature stories, and a handful of national qigong associations, such as the China Qigong Scientific Research Society (Zhongguo qigong kexue yanjiuhui 中國氣功科學 研究會), affiliated to the state sports, Chinese medicine, and science institutions, which facilitated masters' national lecture tours and training workshops. While mass qigong activities in parks and public spaces were free, qigong activities generated considerable revenue through fee-charging lectures and workshops, qigong healing services, the sale of books and instructional videos, and sideline products such as water or tea leaves said to be imbued with the master's healing $q i$. Revenues were typically split between the master who delivered the $q i$ and his method, and the state-sponsored association which used its official, legal status and government connections to organize the lucrative lectures and workshops in various Work Units (Palmer 2007).

Although the state-sponsored associations federated the leading qigong masters into a common organizational framework, there was fierce competition among the masters, who tried to attract more followers and even to poach practitioners from each other, by touting their superior healing powers, the antiquity or authenticity of their methods, the greater ease of learning of the techniques, the higher level of comprehensiveness of their systems, and the lower risk of "qigong deviations" (mental troubles caused by extreme qigong practice). This 
competition produced both standardization, as masters imitated each other in mimetic rivalty, and differentiation, as they each promoted some unique formula or model, sufficiently different from the others as to demarcate itself, but sufficiently similar as to remain within what had emerged as the conventional norms of a good qigong method.

We clearly see the features of a market here. However, market relations were only part of the complex structure of the qigong milieu. At the grassroots, qigong was not driven by market exchanges, but by free activities in public spaces, often initiated by volunteers, constituting a gift economy of people helping and encouraging each other, and offering each other social support as well, forming a mass movement closely linked to the culture of popular, self-organized morning activities in parks. These masses of practitioners, however, formed the pool of potential customers which qigong masters and their organizations tried to turn into a market for their books, videos, training programs, and other products. And this market activity was structured and even made possible by the state-sponsored qigong associations and various government departments which organized and legitimized what was officially designated as the "qigong sector" (qigongije 氣功界), in a way that was typical of the governmental culture of post-Mao China. Thus the qigong movement included, simultaneously and in mutual interaction, (1) a gift economy of grassroots self-organization, (2) commercial entrepreneurship and market relations, and (3) Chinese socialist political organization.

All three of the above entailed different dynamics of social relations, each of which had its own logic. While most qigong groups combined all three to varying degrees, some qigong groups consciously attempted to align themselves with only one logic. Zhonggong, for instance, which was the largest qigong organization in the first half of the 1990's, with a claimed following of 30 million, explicitly adopted a commercial corporate structure. Unlike most other qigong groups, instead of working under the umbrella of a state-sponsored qigong association at the national level, it registered its headquarters as a private company, developed a franchise model, gave financial incentives to its local branches and core practitioners, trained its leaders with Harvard MBA textbooks, and promoted a qigong method which maximised the efficiency of $q i$ production as well as profit generation (Palmer 2011a). On the other hand, Falungong, which was launched by Li Hongzhi 李洪志 in 1992 like any other qigong movement by charging fees for workshops and healing sessions 
facilitated by the state-sponsored China Qigong Scientific Research Society, from 1994 onwards stopped holding workshops, and from 1996 disaffiliated itself from the Society. Falungong moved away from commercial exchange and integration in state institutions, positioning itself almost entirely within the sphere of autonomous self-organization, linking tens of thousands of local practice groups at the grassroots into a massive national network of millions of followers, not customers. This was possible because many practitioners felt gratitude and loyalty to Falungong for healing their illnesses and improving their health. Li Hongzhi stressed that their benefits came from the power of the master and his method, which he was selflessly offering to save the suffering multitudes. This was an important factor in Falungong's popularity in the late 1990's, even as most qigong groups were declining. While a trend of rampant commercialization in the qigong milieu dismayed growing numbers of pratitioners, Falungong stressed the strictly free and non-commercial nature of its activities, placing itself firmly in the gift economy (the sale of Li Hongzhi's books, which were national bestsellers, did provide a lucrative income stream, but this was a sideline to the core relationship between the master and his followers). Falungong then eclipsed all other groups, becoming the largest qigong movement in China by the end of the 1990s, until it it was suppressed from 1999 onwards. Following this, the entire state-supported infrastructure of the qigong movement was dismantled (Palmer 2007).

\section{Diverging approaches to Daoist cultivation}

The commodification of religious cultural resources is a highly controversial issue in China today, widely debated in the media, among academics, and within religious circles. In August 2010, a heated polemic erupted around the case of Master Li Yi 李一, a young Daoist priest and manager of a monastery in the hills outside the city of Chongqing. This priest skilfully packaged Daoist meditation, health and healing practices, and attracted thousands of followers among well-heeled businessmen and pop stars, who came from all over China to follow his treatments and workshops. His temple prospered, and he quickly rose in the ranks of the state-run Daoist administration, being elected Deputy Chairman of the China Daoist Association in June 2010. His rapid success was not unanimously 
appreciated in Daoist circles, however. For some, he had found the key to making Daoism relevant and attractive to contemporary Chinese, combining age-old health secrets with modern marketing savvy. For others, however, the very fact that he was making fame and fortune out of Daoist techniques, was an unmistakable sign that his activity was not true Daoism. One Daoist wrote that such types of masters are "nothing more than itinerant swindlers," that their appearance was a sign of the "sinking" of the teachings, that, in the Daoist circle, "profiteers are numerous, and the righteous few." These comments were made to me by the former deputy chairman of the Daoist Association of a famous Daoist sacred mountain, a gifted and widely admired young monk who was deeply devoted to his spiritual cultivation, and appeared set for a promising career in Daoist officialdom. However, dismayed by the politicization and commercialization of religious life in the monasteries, which, for him, was contributing to the decline of the religion, he had once considered launching a Daoist reform movement, perhaps a new sect which could purify the religion of its worldly corruption. But after much reflection and prayer, he came to the conclusion that there was no authoritative basis in the Daoist scriptures for launching a new movement, and so, instead, he decided to resign his leadership position in the Daoist Association, quit the monastic order, and live as an unknown urban hermit. He lives a simple life in a large city, has a small handful of disciples, and occasionally gives talks to groups that seek him out. Financially independent through support from his parents, material subsistence is not a concern for him, as long as he lives a simple and frugal lifestyle. In his relations with his disciples, he charges no fee; his teachings and advice are offered as a gift, and the essence of his advice is to avoid the desire for rewards from others - by giving of oneself to others, one will receive powers from gods and spiritual forces. An American entrepreneur, founder of a firm which sells Daoist qigong retreats and tours, offered to partner with him to offer lucrative packages for foreign tourists, but he refused, preferring to remain in obscurity and avoid being drawn into business schemes. In this case, our Daoist was critical of the marketization of Daoism, and even considered founding a sect, but, in the end, decided to stay completely outside the market. According to the religious market model, this individual is a "loser," having only less than a dozen disciples, while the "winners" are the dynamic entrepreneurs who are able to capture a growing portion of the market for health and spiritual seekers, drawing thousands of clients; and it is the competition among such entrepreneurs which would make them more efficient providers of Daoist services and, 
ultimately, revitalize Daoism. For him, however, such commercial practices strip Daoism of its spiritual essence, and the ultimate loser would be Daoism itself. Without passing judgement on this Daoist's grim assessment, what is important for my argument here is that the marketization of religion is the subject of a conscious critique within the religion itself, associated with religious behaviour which deliberately minimises market relations, and a norm of spiritual progress which is explicitly at odds with economists' measures of success.

There is nothing new about these debates: the tension between the worldly commercialization of magical techniques and the otherworldly hermit ideal runs through Daoist history. And the critique of profiteering by Daoist priests and Buddhist monks is an age-old theme in Chinese literature, often taken up by literati advocates of a pure spirituality, whom Vincent Goossaert calls "Confucian fundamentalists" (Goossaert 2006). This anticlerical discourse had real consequences: in the late $19^{\text {th }}$ century and early $20^{\text {th }}$ century, it contributed to the denigration of Chinese religion, temples, and the Daoist and Buddhist clergies by China's elites, to the positive reception of Christianity by a significant portion of the elite, and to the launching of Buddhist and, to a lesser degree, Daoist reform movements (Welch 1968; Nedostup 2009; Goossaert and Palmer 2011). These movements aimed to expurgate the "superstitious" ritual and magical services of clerics, to focus on purely spiritual and ethical pursuits, and, in consequence, to remove the religion from market relations.

\section{A Confucian volunteer movement}

I now turn to a Confucian volunteer movement in Beijing, the Yidan Xuetang 一耽 學堂 (see Billioud 2011), on which I have conducted interviews and ethnographic observation between 2008 and 2010. This is a group established in 2001, which takes inspiration from the life and writings of ancient and modern Chinese figures who exemplify an ideal of self-cultivation through the integration of thought and social praxis - ranging from Confucius himself to the early $20^{\text {th }}$ century Confucian reformer Liang Shuming 梁漱溟 (1893-1988), but also including Liang’s contemporary Wang Fengyi 王鳳儀 (1882-1938), a charismatic rural healer and promoter of girls' education, and even Mao Zedong (1893-1976) 
in his youth. The movement's founder, Pang Fei 逢飛, a philosophy graduate of Peking University, explains that it was the sight of crowds in the smoggy streets of Beijing, hurrying about here and there, in blind pursuit of their ambitions, walking in the same space but unconcerned for each other, which led him to wonder if it might be possible to rely on his natural dispositions to do something worthwhile for society. He established a group of student volunteers from several universities, who study the Confucian classics in small groups, give free lessons on the classics in primary schools, assemble at dawn to recite the texts, visit old army veterans and revolutionary activists, as well as rural villages, to absorb the moral lessons from their life stories and folk customs, and support the efforts of retired people to establish academies to teach moral education to children. From its student core, Yidan Xuetang volunteers now include young professionals and seniors, and there are groups in over a dozen Chinese cities.

Since Yidan Xuetang takes its inspiration from Confucius, and the study and teaching of Confucian classics is an important part of its work, it has found itself associated with the broader trend of Confucian revivalism and National Studies (guoxue 國學), one of hundreds of groups, academies, enterprises and government agencies which, in a variety of ways, promote Confucian texts and traditions. It attracts as volunteers young and older people who wish to connect with China's moral tradition and do something of value to society. Pang Fei is regularly invited to Confucian forums, events, and conferences sponsored by various public and private organizations. However, he is harshly critical of much of what goes on under the label of Confucianism, National Studies and classicsrecitation. He is especially critical of a tendency by local governments and official agencies, in alliance with private businesses, to stage Confucian-related events and promotions to build legitimacy or stimulate economic development. Although he willingly associates with the government and uses official slogans in his own discourse in order to provide official cover for his work, he has refused to engage in the logic of state-business collaboration which governs much of the officially-sponsored promotion of Confucianism and traditional culture, leading to the packaging of Confucianism into educational, entertainment, cultural and tourism products and event productions. As a result, there is little substance to Yidan Xuetang's official relationships, the legal status of his organization remains weak, and it operates with bare-bone financial resources. 
Beyond refusing to engage in market relations, Pang Fei also refuses to engage in a quasi-market "promotion" of Confucianism and traditional culture. He is dismissive of projects to "disseminate" and "promote" (tuiguang 推廣) traditional culture, which may serve to increase the visibility of aspects of Chinese tradition or Confucianism, and increase people's identification with it, but actually do nothing to change the moral structure of society - simply adding a Chinese/Confucian dressing to a modern way of life in which the moral spirit remains absent. Thus, Yidan Xuetang does not emphasize an identity according to a label such as "Confucian" - the focus is on nurturing and expressing the moral spirit of the Chinese people through promoting volunteer activities in which participants can find an outlet for their innate desire to show care and concern for each other. The spirit of volunteer involvement is more important than any concrete results: Pang Fei also rejects the "project" management model of many NGOs and foundations, in which activities are organized and funded with fixed objectives in mind. In organizing volunteer university students to teach the classics in primary schools, he refuses to advocate any specific teaching method or to train the volunteers, stressing the spirit of selfless giving and service, which touches the childrens' hearts more than any pedagogical technique.

Thus, Yidan Xuetang rejects all forms of instrumental rationality, whether it involve promoting traditional culture to an ever-larger population, or project design and management for more efficient delivery of social service or educational programmes. Such approaches, for Pang Fei, may distort the human spirit which is at the core of Yidan Xuetang's work. In spite of early attempts to create rationalized organizational structures, the result is a loosely organized movement, in which enthusiasm is more important than systematization, and which, by Pang's own admission, is "constantly on the brink of life and death." Here again, we see a case of consciously rejecting market relations, as well as the marketing culture of devising effective methods to "promote" one "brand" of Confucianism and recruit adherents to this brand. Yidan Xuetang is consciously seeking to create a space which is entirely outside the market and its models of operation. This space, founded on service to others through volunteerism, involves an expanding gift economy. And although Yidan xuetang is not explicitly religious, the logic of exchanges is similar to that of a religious gift economy: the collective memory of Chinese civilization and its sages is what is 
honoured; and the way to show gratitude and respect for Chinese tradition is to embody the generosity of the Chinese spirit by helping others.

\section{A charismatic Buddhist healer and philanthropist}

With the extraordinary growth of China's economy over the past decades, a new generation of successful business entrepreneurs and billionnaires has appeared, most of whom are incarnations of dreams of "rags to riches." At the same time, the gap between the rich and poor has widened, and, far (and sometimes not so far) from the booming cities of the coasts, China's impoverished rural hinterlands often suffer from declining public investment in health and education. Many of the new barons of business have established charitable foundations to help alleviate poverty - a growing trend which is promoted by the Chinese state. In a bid to publicize generosity and encourage charity, many magazines and government bodies regularly publish honor rolls and lists of China's "top philanthropists". Most of them are wealthy real estate developers and pop stars - but one name that has been honoured is that of an illiterate, 80-year-old former beggar, Lin Dong 林東, a charismatic Buddhist healer who has donated tens of millions of dollars to build schools in poor villages all over China.

Born in 1930 in Putian 莆田, Fujian, Lin Dong became an orphan during his childhood and began a life of errant mendicacy. He married another beggar and, after the Peoples' Republic was established in 1949, was assigned a job as a manual laborer, helping to ship loads of goods along the waterways of Guangdong province. In the 1970's his right hand was chopped off in an accident, and a few years later he suffered from a stroke. In a state of near death, he had a vision of the Chinese Buddhist saint Jigong 濟公, who assured him that he would recover and entrusted him with the mission of rescuing those who suffer in the world.

After his vision of Jigong and his seemingly miraculous recovery from his stroke, Lin Dong established an altar to him and worshipped him in his home, and discovered that he had uncanny healing powers. The sick flocked to him from all quarters. He dictated prescriptions of Chinese herbs and exhorted them to do good deeds, to accumulate good 
karma and attain cosmic recompense. Many were cured and became his followers. Full of gratitude to him for saving their lives, they are willing to do anything for him. Lin Dong encourages them to donate money, and they gladly respond; living a simple life and wearing cheap clothes, he offers all the funds collected to build schools and homes for the aged. As a result, although he has no wealth of his own, Lin Dong has raised and donated sums comparable to those given by China's richest business tycoons. And for those of his followers who have little money to offer, he encourages them to offer their time as volunteers, visiting the poor and the elderly.

Lin Dong's experience and philanthropic actions are deeply rooted in China's religious culture of cosmic recompense. "To become a Buddhist", he says, "is like opening a bank account: we should try our best to make credits through good deeds, instead of continuous debits; if we continuously draw from the account we will have a deficit, and if we do not make repayment to the overdrawn account, nobody will help us to settle it. The more industriously we foster charitable deeds, the more our recompense will increase." (A Paradise 2008).

This example describes a system of economic relations at many levels. We see a charismatic healer as the central node of flows of healing energy and money: healing power understood to be flowing from the god Jigong to him and from him to sick clients, and philanthropic donations flowing from his clients to him and from him to recipients. Exchanges occur both at a material and spiritual level, and banking metaphors are even used to explain how to obtain spiritual rewards.

But is it a market? Lin Dong is listed as one of many Chinese philanthropists. The others are successful business entrepreneurs. As with Lin Dong, money comes their way and they distribute it to others. Does this mean that they are operating within the same logic of exchange? If so, why does Lin Dong donate most of his income, and the business leaders only donate a small fraction? Lin Dong has a thousand devoted followers who are ready to freely donate their cash to him, fully trusting in him and what he does with it, and who remain tied to him and his gods even long after they have "paid back" for their cures. Why don't any of the business leaders have such followers, in spite of their philanthropy? Is Lin Dong's Buddhist organization really a "firm" in the same sense as those business entrepreneurs' real estate development corporations? 
The religious market theory solves these problems through concepts of "compensators" (Stark and Bainbridge 1985: 6) or, in more recent iterations, "otherworldly rewards" (Stark and Finke 2000: 277). The reference to otherworldly rewards in Lin Dong's case is explicit, and even couched in monetary terms. Through their charitable donations, one can say that Lin Dong's followers are purchasing otherworldly rewards. Stark and Finke have put their finger on the crux of the matter. But the crucial question should then be, what type of economy is created when otherworldly or spiritual rewards are added to the equation?

A market exchange is a dyadic relationship in which pay-outs and rewards are given and received by the two parties only (or their proxies). In the religious relationships exemplified by the case of Lin Dong and his followers, however, a different logic is at work. Here, the rewards are spiritual and are understood to come from a spiritual source; they are described with terms such as gongde 功德 (karmic merit) or baoying 報應 (cosmic recompense). Obtaining these spiritual rewards is an explicit goal, and motivates giving behaviour - but the rewards are expected from a spiritual source and not from the receiver of the gift. Neither Lin Dong, nor the recipients of charitable aid, are expected to return a favour or service in exhange for the donation. One does not enter into relationships with people in order to obtain reciprocal rewards from them, but from a "third party" - the spiritual or divine source of rewards. When Lin Dong offers free healings, or when he offers generous philanthropic donations, he asks for nothing in return; and such benevolence is understood as generating infinitely more valuable spiritual rewards. At the same time, Lin Dong's patients feel gratitude and a desire to reciprocate - but Lin Dong encourages them to express their gratitude by doing good deeds for others than bimself through volunteering and philanthropic donations, replicating the pattern of Lin Dong's altruism and generating spiritual rewards for themselves. And Lin Dong's altruism is patterned on his relationship with the god Jigong, who healed him from his own sufferings; and whom he is thanking through his compassionate deeds for others. Rather than the calculated mutual costs and benefits of a closed diad of reciprocal exchanges, the result is a culture of giving and an expanding community in which social relationships are based on service to others.

To be sure, the participants in this network gain many worldly rewards as well. Lin Dong visibly enjoys the attention of his grateful followers and eagerly seeks public recognition for his deeds - claiming that he hopes, through his example, to encourage 
thousands of people to become philanthropists. His followers, in addition to their healings, gain a warm and caring social network, and new, empowering social roles. One may wonder to what extent Lin Dong and his followers are sincerely motivated, or if they are mainly drawn by the palpable social rewards which accrue to them, or some combination of the two. But the question is perhaps irrelevant, since the two classes of rewards do not necessarily exclude each other. Most important is that the very structure of the social relations of this community is based on the religious principles of this-worldly altruism for otherworldly rewards - an economy of exchanges between people in which one does not seek rewards from other people, but from the gods and karmic recompense. And it is because of this logic of exchanges that Lin Dong and his movement are in a different class from businessmen and their firms.

\section{Analysis}

The cases I have presented are quite diverse, and the first conclusion to be drawn is that each case encapsulates a complex combination and interpenetration of different modalities of exchange, of which market and gift relations are only two of several possible modes of sociality.

Our cases show that market exchanges do exist in the religious sphere: there are markets for religious books; markets for religious objects, amulets and so on; markets for religious services ranging from funeral rituals to training courses; markets for religious and spirtual tourist products ranging from scenic spots to hotels, package tours, and so on. Religious markets are indeed an inevitable component of the total market economy of any society. However, these represent only part of the picture, while gift economies are at the core of the religious groups and movements studied.

Furthermore, in the three cases of the Daoist urban "hermit", the Confucian "volunteer", and the Buddhist "philanthropist", we see conscious attempts to generate forms of relating to others which would result from a spiritual practice and orientation to life. While the hermit and the volunteer explicitly critique the marketization of China's spiritual tradition, and consciously position themselves outside the logic of the market, the 
philanthropist, following the god and karma, upsets the conventional rationality of financial flows. While all three have a message which they are devoted to sharing with others, their sensitivity to the spiritual quality of social relations is more important than numerical objectives such as numbers of members or the extent of the spread of their message. These are entirely non-market forms of social relations, which, each in a different way, are premised on giving and obligation.

If we refer to the five "modalities of doing religion" described by Chau in his contribution to this issue, we may find that although both market and non-market relations can be found in each of the modalities, there may be more or less affinity between a specific modality and a specific model of exchange. For example, the "immediate-practical" modality lends itself easily to market exchanges through the provision, for a fee, of one-off magical rites or divination services for individuals or the sale of charms and talismans. In the "discursive-scriptural", the "personal-cultivational" and the "liturgical" modalities, we can find both market and non-market forms, either combined in a single event production such as the communal jiao rituals or in the organizational infrastructure of mass qigong movements, or in conscious opposition to each other, such as in competing views and practices of Daoist cultivation or Confucian revivalism. The "relational" modality, however, consisting of building social relations between humans and deities (or ancestors) and between human worshippers, and based on notions of laiwang 來往 and guanxi 關係 (Chau, this issue, p. __), seems by definition to be based on a gifting model.

Awareness of the difference between market and non-market relations runs through the Chinese religious field, in which actors, consciously or not, position themselves as market or non-market operators, reflect and debate on the merits of both modes of operation, and sometimes build their identity around their acceptance or rejection of commercial models. The distinction between market and non-market relations produces shifting and contested lines of differentiation in the Chinese religious field, cutting through religious traditions.

Given this variety of forms of exchange, a useful question would be to ask under what conditions different forms expand or contract. Indeed, we can speak of a process of "marketization" of religion, when an increasing range of religious activities becomes subsumed under the logic of market transactions. A detailed treatment of this question is 
beyond the scope of this article. But a few observations may be useful: (1) there is nothing new about the marketization of various forms of religious services and practices in China, which has been widespread at least since the Song dynasty, from the $10^{\text {th }}$ century onwards (von Glahn 2004); (2) since the $20^{\text {th }}$ century, urbanization and the shift away from from the sedentary, ascriptive communities of agrarian culture, to the more mobile, unaffiliated populations of immigrant metropolises - as well as the subsequent weakening of communal religious culture, further reinforced by political campaigns and restrictions, has vastly increased the population who lack religious knowledge, culture and community, and thus constitute a vast potential market for those who would provide packaged solutions to unaffiliated individuals. The expansion of the market economy has provided favourable conditions for those forms of Chinese religion which have traditionally operated as what Stark and Bainbridge call "client cults" (Stark and Bainbridge 1985: 209); while other types of ascriptive communal religion have, in the big cities, either withered and disappeared (when not banned outright), or transformed themselves to adapt to the logic of market relations. (3) Owing to restrictions on non-governmental and non-commercial forms of association in China, and to the government's preference for economic development as the main sphere for the deployment of social forces and cooperation between the state and society, there is more legal space for the development of marketised derivatives of religion than nongovernmental quasi-market or non-market forms. All of these factors create the objective conditions for the increasing marketization of religion in China - a trend which can only be reinforced by the pervasive commercialization of ever greater realms of culture in general.

At the same time, these same objective conditions also lead to an opposing tendency - a desire for other forms of social relations and orientations in life, which are not tainted by the instrumental exchanges of commercial life. Both outside and inside religious communities, a discourse arises which condemns the commercialization of religious practices, and aspires for a more pure form of religion. Robert Weller (1999: chapter 5), looking at the case of Taiwan, has indeed argued that the rise of a market economy leads to what he calls a "split market" religious culture in which we find two types of religious actors: while amoral cults fetishize market relationships, moralizing religions attempt to create an alternative type of community based on a non-commercialized morality - even as they help their members to function successfully in the market economy. Weller attributes the growth of Yiguandao to this tendency. As discussed above, Falungong also corresponded to a similar tendency in 
mainland China in the 1990s - and, today, the same could probably said of much of the spectacular growth of Christianity (F. Yang 2005; Cao 2011).

Both critics (Bruce 1993) and defenders (Iannacone 1995) of the market theory have noted the commodification of religion in North America and debated whether this trend explains the theory itself - but neither have addressed the distinctions, competition, and mutual influences between commercial forms of religion and those that are not. To the extent that consumerism and marketing have become pervasive in contemporary culture, business attitudes and practices have even seeped into non-commercial religious groups, some of which adopt corporate models of management and marketing - as described by Cao Nanlai in his study of Christian entrepreneurs and their churches in the coastal city of Wenzhou. On the other hand, if these "boss Christians" zealously contribute to the development of their churches in order to convert economic into cultural capital, it is precisely because the non-commercial nature of the churches is perceived as having a different quality and legitimacy, which is lacking in their business enterprises (Cao 2010: 9596). It is thus puzzling that the market theory of religion is oblivious to the distinction between market and non-market exchanges: indeed, the most significant competition and interpenetration is, perhaps, that between the two forms of social relations.

Religious market theorists might respond that such scenarios, and the religious gift economy I have outlined, simply describe another type of market: these are diverse ways of purchasing otherworldly rewards. Such groups are producing a supply of non-commercial religious life, meeting a demand in society. According to this reasoning, whenever there is a dynamic of supply and demand, there is a market, no matter the form of exchange. But surely one would not call family relations a "market" on account of the presence of multiple "suppliers" to meet the "demand" for love, even in the presence of competition for affection. Nor does a community constitute a "market" when residents, through informal acts and organized projects, "supply" volunteer services to the community to meet its needs or "demands."

When religious groups engage in a conscious critique of the commercialization of human relations and attempt to exemplify an alternative; and when marketization, by weakening traditional forms of solidarity, creates both the conditions and the demand for such alternatives, we are surely dealing with a phenomenon of sociological significance -- 
which merits being highlighted in any conceptual framework, rather than papered over by subsuming it into an expanded definition of a market.

In this article, I have outlined the religious gift economy as a model of non-market relations arising from the observation and analysis of ethnographic cases in China. I have noted how market and gift economies coexist, compete, and combine in complex ways. I have discussed the trend of religious marketisation, which accompanies the weakening of ascriptive religious gift economies, but also a growing thirst for new forms of non-market sociality and religious life. To be sure, a religious gift economy is not the only possible model of non-market relations in the religious sphere, and there are undoubtedly other types of non-market relations which do not fit into the gifting model. Owing to lack of space, this article has merely offered a preliminary sketch of these issues. Only further research can explore the many other implications of the contrast and interplay between market and nonmarket relations in the religious economy.

The religious market theory opens a host of fruitful questions for scholars of religion. We face a choice between two strategies of investigation. The first is to postulate that all religious behaviour constitutes a market exchange. And, undoubtedly, valuable insights can be gained from applying market metaphors to other fields, just as theories of religion have been used to analyse non-religious phenonena such as football matches or political movements. But, as Stark and Bainbridge have themselves stressed, such a conceptual extension, by erasing the distinction between groups that do or don't base themselves on supernatural beliefs, makes it impossible to theorize the link between such beliefs and social behaviour: "to do so makes it needlessly difficult to explore conflicts between these contrary systems of thought or to identify the rather different capacities present in each"; in fact, "it makes no more sense to equate them than to equate totem poles and telephone poles." (Stark and Bainbridge 1985: 3). I contend that the same logic applies to the extension of market concepts: the link between market relations and human behaviour can only be understood if the concept of the market is only applied to market relations, strictly defined, and not to relationships which lack the defining characteristics of a market transaction.

The second strategy, then, is to empirically identify those types of religious behaviour which are market relations, to analyse their properties, and derive models of their dynamics. But since such an exercise will inevitably lead us to identify other, non-market types of 
religious relations, new questions arise as to the nature of these non-market relations. What are their properties; are there different models of non-market religious relations; what are their dynamics? How do they contrast with each other and with market relations? How do they interact with each other? To blanket all of these under a single, extended concept of the market obscures the fundamental distinctions between them and, ultimately, blots out the primary question of the sociology of religion: what types of social relations are constituted by religion?

\section{Acknowledgements}

This article is an output of the project "Volunteerism in China: Moral Discourse and Social Spaces", funded by the General Research Fund of the Hong Kong Universities Grants Council. I would also like to warmly thank Philip Clart, Joachim Gentz, Thomas Jansen, Thoralf Klein, and Christian Meyer for inviting me to the workshop on "Beyond the Religious Market" at the University of Wales at Lampeter in December 2009, as well as the workshop participants and the reviewers for Religion for their valuable comments and suggestions, which have greatly enriched the ideas in this article.

\section{References}

A Paradise on Earth - Tung Cheng Yuen founded by Mr. Lam Tong. 2008. DVD produced by Tai Tak Production Co., Hong Kong.

Alles, Gregory D. 2000. Exchange. In Guide to the Study of Religion, ed. Willi Braun and Russell T. McCutcheon, eds. London \& New York: Continuum, pp. 110-124.

Billioud, Sébastien. 2011. Confucian Revival and the Emergence of Jiaohua Organizations: A Case Study of the Yidan Xuetang. Modern China 37/3: 286 - 314.

Bloch, Maurice, Jonathan Parry, eds. 1989. Money and the Morality of Exchange. Cambridge: Cambridge University Press.

Bruce, Steve. 1993. Religion and Rational Choice: A Critique of Economic Explanations of Religious Behavior. Sociology of Religion 54: 193-205.

Cao, Nanlai. 2011. Constructing China's Jerusalem: Christians, Power, and Place in Contemporary Wenzhou. Stanford: Stanford University Press.

Chan, Selina and Graeme Lang. 2011. Temples as Enterprises. In Religion in Contemporary China: Revitalization and Innovation, ed. Adam Yuet Chau. Abingdon, Oxon: Routledge, 133-153.

Chan, Yuk Wah. 2003. Packaging Tradition: Chinese Death Management in Urban Hong Kong. Asian Anthropology 2: 139-60.

Chau, Adam Yuet. 2005a. Hosting Funerals and Temple Festivals: Folk Event Productions in Rural 
China. Asian Anthropology 3: 39-70.

. 2006a. Miraculous Response: Doing Popular Religion in Contemporary China. Stanford: Stanford University Press.

.2006b. "Superstition specialist households"? The household idiom in Chinese religious practices. Minsu quyi 民俗曲藝/Journal of Chinese Ritual, Theatre and Folklore 153: 177202.

Clart, Philip. 2009. Merit Beyond Measure: Notes on the Moral (and Real) Economy of Religious Publishing in Taiwan. In The People and the Dao: New Studies in Chinese Religions in Honour of Daniel L. Overmyer, ed. Philip Clart and Paul Crowe. Sankt Augustin: Institut Monumenta Serica, 127-142.

Dean, Kenneth. 1993. Taoist Ritual and Popular Cults of South-East China. Princeton: Princeton University Press.

. 1998. Lord of the Three in One. The Spread of a Cult in Southeast China. Princeton: Princeton University Press.

. 2009. Further Partings of the Way. In Making Religion, Making the State, ed. Yoshiko Ashiwa and David Wank. Stanford: Stanford University Press, 179-210.

Dean, Kenneth and Zhenman Zheng. 2010. Ritual Alliances of the Putian Plain (2 vols.). Leiden: Brill.

Duara, Prasenjit. 1988. Culture, Power, and the State. Rural North China, 1900-1942. Stanford: Stanford University Press.

Eng, Irene, Yi-Min Lin. 2002. Religious Festivities, Communal Rivalry, and Restructuring of Authority Relations in Rural Chaozhou, Southeast China. Journal of Asian Studies 61/4, 1259-85.

Farquhar, Judith. 2009. The Park Pass: Peopling and Civilizing a New Old Beijing. Public Culture 21/3: 551-576.

Gates, Hill. 1996. China's Motor: A Thousand Years of Petty Capitalism. Ithaca, NY: Cornell University Press.

Finke, Roger, Rodney Stark. 1992. The Churching of America, 1776-1990: Winners and Losers in our Religious Economy. New Brunswick, NJ: Rutgers University Press.

Gernet, Jacques. 1998. Buddhism in Chinese Society: An Economic History from the Fifth to the Tenth Centuries. Trans. Franciscus Verellen. New York: Columbia University Press.

Godelier, Maurice. 1996. L'énigme du don. Paris: Flammarion.

Goossaert, Vincent. 2006. 1898: The Beginning of the End for Chinese Religion? Journal of Asian Studies 65/2: 307-36. . 2011. Daoists in the Modern Self-Cultivation Market: The Case of Beijing, 18501949 In Daoism in the $20^{\text {th }}$ Century: Between Eternity and Modernity, ed. David A. Palmer and Xun Liu. Berkeley: University of California Press, 2011, chap. 5.

Goossaert, Vincent, David A. Palmer. The Religious Question in Modern China. Chicago: University of Chicago Press, 2011.

Gregory, Christopher. 1982. Gifts and Commodities. London: Academic Press.

Kieschnick, John. 2003. The Impact of Buddhism on Chinese Material Culture. Princeton: Princeton University Press.

Iannacone, Laurence R. 1991. The Consequences of Religious Market Structure: Adam Smith and the Economics of Religion. Rationality and Society 3: 156-77. . 1995. Voodoo Economics? Reviewing the Rational Choice Approach to Religion. Journal for the Scientific Study of Religion 34/1: 76-88. 
Jones, Stephen. 2011. Revival in Crisis. Amateur Ritual Associations in Hebei. In Religion in Contemporary China: Revitalization and Innovation, ed. Adam Yuet Chau. Abingdon, Oxon: Routledge, 133-153.

Lai Chi-tim, Yau Chi-on and Wu Zhen. 2009. Xianggang daojiao 香港道教 [Hong Kong Daoism]. Hong Kong: Zhonghua shuju.

Lang, Graeme, Lars Ragvald. 1993. The Rise of a Refugee God. Hong Kong’s Wong Tai Sin. Hong Kong: Oxford University Press.

Lang, Graeme, Selina Chan and Lars Ragvald. 2005. Temples and the Religious Economy. In State, Market, and Religions, ed. Fenggang Yang \& Joseph Tamney. Leiden: Brill, 149-80.

Lu Yunfeng. 2005. Entrepreneurial Logics and the Evolution of Falun Gong. Journal for the Scientific Study of Religion 44/2: 173-85.

- 2008. The Transformation of Yiguan Dao in Taiwan: Adapting to a Changing Religious Economy. Lanham, MD: Lexington Books.

Malinowski, Bronislaw. 1922. Argonauts of the Western Pacific. London: Routledge and Kegan Paul.

Mauss, Marcel. 1967 [1925]. The Gift: The Forms and Functions of Exchange in Archaic Societies. trans. Ian Cunnison. New York: W. W. Norton.

Nedostup, Rebecca. 2009. Superstitious Regimes: Religion and the Politics of Chinese Modernity. Cambridge, MA: Harvard University Asia Center.

Palmer, David A. 2007. Qigong Fever: Body, Science, and Utopia in China. New York: Columbia University Press.

. 2008. Embodying Utopia: Charisma in the post-Mao Qigong Craze, Nova Religio 12/2: 69-89.

. 2011a. Chinese Religious Innovation in the Qigong Movement: The Case of Zhonggong. In Religion in Contemporary China: Revitalization and Innovation, ed. Adam Yuet Chau. Abingdon, Oxon: Routledge, 182-203.

- 2011b. Chinese Redemptive Societies and Salvationist Religion: Historical

Phenomenon or Sociological Category? Minsu quyi 民俗曲藝/Journal of Chinese

Ritual, Theatre and Folklore 172.

. 2011c. The Jiao Tradition of the Local Priests of Huanghua Township, Yingde, Guangdong. International Workshop on the Comparative Ethnography of Local

Daoist Ritual, University of Hong Kong, April 21-23.

Polanyi, Karl. 1968. Societies and Economic Systems. In Primitive, Archaic and Modern Economies: Essays of Karl Polanyi, ed. George Dalton. Boston: Beacon Press, 3-25. . 1977. The Livelihood of Man. (Edited by Harry W. Pearson). New York: Academic Press.

Sahlins, Marshall. 2004 [1972]. Stone Age Economics. Abingdon: Routledge.

Seiwert, Hubert Michael, in collaboration with Ma Xisha. 2003. Popular Religious Movements and Heterodox Sects in Chinese History. Leiden: Brill.

Sharot, Stephen. 2002. Beyond Christianity: A Critique of the Rational Choice Theory of Religion from a Weberian and Comparative Religions Perspective. Sociology of Religion 63/4: 427-54.

Sykes, Karen. 2005. Arguing with Anthropology: An Introduction to Critical Theories of the Gift. Abingdon and New York: Routledge.

Stark, Rodney. 1996. The Rise of Christianity: A Sociologist Reconsiders History. Princeton: Princeton University Press. 
Stark, Rodney, William Sims Bainbridge. 1985. The Future of Religion: Secularization, Revival, and Cult Formation. Berkeley: University of California Press. . 1996[1987]. A Theory of Religion. New Brunswick, NJ: Rutgers University Press.

Stark, Rodney, Roger Finke. 2000. Acts of Faith: Explaining the Human Side of Religion. Berkeley: University of California Press.

Tam, Wai-lun. 2009. Cong Yuebei Yingde de ‘nahm-mouh' jiaoyi kan minjian fojiao 從 粵北英德的 ‘喃舆”醮儀看民間佛教 [A perspective on popular Buddhism from the Nahm-mouh jiao rituals of Yingde, Northern Guangdong]. Minsu quyi 民俗曲藝/Journal of Chinese Ritual, Theatre and Folklore 163: 71-115.

Von Glahn, Richard. 2004. The Sinister Way: The Divine and the Demonic in Chinese Religious Culture. Berkeley: University of California Press.

Weiner, Annette. 1992. Inalienable Possessions: The Paradox of Keeping-While-Giving. Berkeley: University of California Press.

Welch, Holmes. 1968. The Buddhist Revival in China. Cambridge, MA: Harvard University Press.

Weller, Robert. 1999. Alternate Civilities: Democracy and Culture in China and Taiwan. Boulder, CO: Westview.

Yang, Fenggang. 2005. Lost in the Market, Saved at Mcdonald's: Conversion to Christianity in Urban China. Journal for the Scientific Study of Religion 44/4: 423-41. . 2006. The Red, Black, and Gray Markets of Religion in China. The Sociological Quarterly 47: 93-122.

. 2010. Religion in China under Communism: A Shortage Economy Explanation. Journal of Church and State 52/1: 3-34.

Yang, Mayfair Mei-hui. 1994. Gifts, Favors, and Banquets. The Art of Social Relationships in China. Ithaca, NY: Cornell University Press.

. 2000. Putting Global Capitalism in Its Place. Economic Hybridity, Bataille, and Ritual Expenditure. Current Anthropology 41/4: 477-509. 